\title{
IMPERATIVES OF A SUCCESSFUL MEDICAL CAREER
}

Swende T.Z..

A Guest Lecture on the Occasion of the Professional Induction and Admission Ceremony for the 2018 Medical Grandaunds of the College of Health Sciences Benue State University Makurdi on 23rd Day of May, 2018.

Correspondence: Professor Terrumun Z. Swende, Department of Obstetrics and Gynaecology, College of Health Sciences, Benue State University, Makurdi, Nigeria. Email: swendetz@yahoo.com

'It is our proud office to tend the fleshy tabernacle of the immortal spirit, and our path, if rightly followed, will be guided by unfettered truth and love unfeigned", Joseph Lister (1827-1912)

I consider it a great honour and privilege to be invited to address this solemn and distinguished assembly. I must congratulate the Medical gradaunds we are celebrating and inducting today for successfully applying themselves and surviving the rigors of undergraduate medical education. You have every reason to be happy, likewise your families, teachers, alma mater, Benue State University, the Government and people of Benue State and indeed humanity at large. Becoming a physician is a call to higher and divine service; an unparalleled opportunity of passage into the history of the Greats. Greatness and preeminence I pray you will all achieve and do so through humane, selfless and unblemished medical care/ service to mankind.

It is customary for us in the medical profession on occasions such as this to recall with reverence and affection medical greats and icons of all time. And so we eulogize here and today Hippocrates, the great ancient physician who was born on the Greek Island of Cos and lived between $460 \mathrm{BC}$ and $375 \mathrm{BC}$. Hippocrates is traditionally regarded as the father of modern western medicine and revered for his ethical standards and his founding of medicine as a rational science. He, it was, who finally freed medicine from the shackles of magic, superstition and the supernatural. It is a modification of his famous oath that these young medical graduands will attest to shortly.

Charity, they say, begins at home. It is with fond, warm and affectionate thoughts that I acknowledge two great and successful world-class physicians of Benue State extraction. First, Prof. Shima k. Gyoh MBBS(1966), FRCS, FWACS, FMCS, OFR a renowned surgeon and quintessential administrator. Famous for his compelling quest for excellence, Prof. Gyoh continues to teach us to put smiles on the faces of our distressed patients. Second, Dr. Ame Idoko $M B B S(1967), F R C P, F W A C P$, FMCPaed, MFR, an acclaimed and most-distinguished Paediatrician, entrepreneur and health administrator. Dr. Idoko's resilience and drive for successful healthcare delivery is legendary.

For obvious want of time and space, may I, with a profound sense of honour, recognize all other outstanding physicians of our time. It is to this long and illustrious list of successful medical practitioners that these young medical graduands seek, and Godwilling, shall join having been found worthy in both character and learning.

Standing on the shoulders of those who have gone before me and drawing from my brief but instructive experience for the better part of two decades as a physician and trainer, I hope to engage the attention and focus of these soon-to-be Hippocratic brethren to a few areas that are pivotal and imperative to success in the medical profession. I implore you to rise above the deserving euphoria of your success and this solemn occasion and lend me your ears and attention. Let me be clear: if you take away nothing from this lecture, remember the words of the Chicago Professor of Surgery John Benjamin Murphy (1857-1916): 'The patient is the centre of the medical universe around which all our works revolve and towards which all our efforts tend" ${ }^{1}$ The patient is the reason you have studied medicine. The patient is the reason you will soon be engaged as House Officers. The patient is the fundamental reason we doctors exist. 
Therefore place the best interests of patients at the centre of everything you do and you are already on your way to success. $^{2}$ Show dedication and commitment to duty at all times. Be compassionate and respectful to all. Be humble and remain team players throughout your career.

As you begin your medical career it is important to imbibe and pay attention to the core values of discipline, hard work and apprenticeship. The demands on medical practitioners, especially younger ones, are enormous. To be able to cope, it is common to find many physicians operating at the limits of their intellectual and physical capabilities. You will find discipline and hard work immensely helpful. Indeed, hard work does not kill; it is the absence of hard work that kills every prospect for success. The Oxford English Dictionary defines an apprentice as: "A learner of a craft, bound to serve, and entitled to instruction from his or her employer for a specified period; also as a beginner or novice.' Medicine as a profession is strictly structured on hierarchy with younger practitioners learning at the feet of more experienced ones. Any attempt to fault this is a recipe for chaos. Accord your superiors every respect due them and you can be sure of their support and guidance beyond your imagination.
You will come to discover that Medicine is a profession next to godliness. As Priests in the Temple of Health, you must eschew all forms of evil. Affirm only that which you have seen and understood. Never append your signature to false documents and medical certificates. The temptations can be particularly enticing as very often such unscrupulous requests come from friends and relatives. Resist monetary inducement in this regard as medical practice is not a short cut to ill-gotten 'wealth'.

The universality of Medicine is widely acknowledged. Treat all patients fairly irrespective of ethnicity, religion, creed or social standing. Do not allow considerations of ethnicity, religion, etc sicken your conscience, enslave your intellect and blur your judgment. You must rise above these parochial interests manifestly entrenched in the larger Nigerian society if you are to achieve a successful career.

Effective doctor-patient communication (verbal and non verbal) is a central clinical function in building a successful doctor-patient relationship, which is the heart and art of medicine. This is very important in the delivery of high quality healthcare. Much patient dissatisfaction and many complaints are due to breakdown in the doctor-patient relationship. ${ }^{3}$ like the eminent Scottish Physician Sir Robert Hutchinson (1871-1960) captured in his famous 'petition' in 1953

\section{'From inability to let well alone}

From too much zeal for the new and contempt for what is old

From putting knowledge before wisdom, science before art, and cleverness before common sense;

From treating patients as cases and from making the cure of the disease more grievous than the Endurance of the same, Good Lord, deliver us.'

The practice of Medicine is both a Science and an Art but we neglect the art to our peril. Wisdom is defined as understanding the limits of one's knowledge and skill. It is said that a person with knowledge is proud that he/she knows so much while a person with wisdom is apologetic that there is so much more to know. Knowing the limits of your knowledge and where you or the patient can access more information/help is important in modern medical practice. ${ }^{4}$

Dream of the future and set your career goals from the outset. To possibilities, there is no end. Thereafter focus and work towards achieving your set career goals as success often comes to those who want it the most. Specialization and sub-specialization are now the rule rather than a choice. The earlier you decide the better. Beyond the regular specialties which you are already well acquainted with in course of your training, other viable alternatives to traditional medical careers include Health Journalism, Healthcare Entrepreneurship, Clinical Forensic Medical Examiners, Medical Photography, Sports and Exercise Medicine, Volunteer Worker, Medical Sales Representative, Medical legal Advisor, Occupational Physician, Health Economics, Health Policy, Health Service Management, Medical Publishing etc. Your choice of specialty should be dictated by your passion and interest above all other considerations.

'The unexamined life is not worth living' is a famous dictum credited to Socrates the Greek Philosopher at his trial for impiety and corrupting youth, for which he was subsequently sentenced to death. ${ }^{5,6}$ The very moment you attest to the oath set 
before you today, you will constantly come under professional and public trial and scrutiny as long as you practice. The measure of your success will be the extent to which you pass such scrutiny, individually and collectively. The interpretation of the dictum 'the unexamined life is not worth living' remains controversial. ${ }^{6}$ Nonetheless, permit me to exploit the 'poetic license' afforded me on this occasion to challenge these young doctors to self $\mathrm{x}$-ray their conduct from time to time so as to make their careers worthwhile.

Success in your chosen career is important. More important, though, is success in your family life. Think early of family and remain loyal to it. As far as possible, without surrender, be on good terms with all persons ${ }^{7}$. Have an abiding faith in your Creator who has brought you thus far.

Finally, I leave you with the full text of the original Hippocratic Oath ${ }^{8}$ which remains potently relevant today, for the most part, as it was yesterday for your reflection:

I swear by Apollo the physician and Aesculapius, and Health and All-heal, and all the gods and goddesses, that according to my ability and judgment, I will keep this Oath and its stipulation- to reckon him who taught me this art equally dear to me as my parents, to share my substance with him, and relieve his necessities if required; to look upon his offspring in the same footing as my brothers, and to teach them this art, if they shall wish to learn it, without fee or stipulation; and that by precept, lecture and every other mode of instruction, I will impart knowledge of the art to my own sons and those of my teachers, and to disciples bound by a stipulation and oath according to the law of medicine, but to none others. I will follow that system of regimen which, according to my ability and judgment, I consider for the benefit of my patients, and abstain from whatever is deleterious and mischievous. I will give no deadly medicine to any one if asked, nor suggest such counsel; and in like manner I will not give to a woman a pessary to produce abortion. With purity and with holiness I will pass my life and practice my art. I will not cut persons laboring under the stone, but will leave this to be done by men who are practitioners of this work. Into whatever houses I enter, I will go into them for the benefit of the sick, and will abstain from every voluntary act of mischief and corruption; and further, from the seduction of females and males, of freemen and slaves. Whatever, in connection with my professional service, or not with it, I see or hear, in the life of men, which ought not to be spoken of abroad, I will not divulge, as reckoning that all such should be kept secret. While I continue to keep this oath unviolated, may it be granted to me to enjoy life and the practice of the art, respected by all men in all times. But should I trespass and violate this oath, may the reverse be my lot.

Thank you all and God bless.

\section{References}

1. Spotlight: Patient-centred care. Time to deliver patient centred care. BMJ. 2015; 350 doi: https://doi.org/10.1136/bmj.h350 (accessed 19th May, 2018)

2. Barnhoorn PC, Youngson CC. Defining professionalism: Simplex sigillum veri! Medical teacher 2014;36 (6):545 doi:10.3109/0142159x.2014.909016

3. Ha FA. Doctor-Patient Communication: A Review. The Ochsner Journal. 2010; 10(1): 38-43
4. Shankar PR. Sir Robert Hutchinson's Petition and the Medical Humanities. International Journal of Medical Education. 2010; 1:2-4

5. Brickhouse TC, Smith ND. Plato's Socrates. 1994; Oxford University Press. Pp 201.

6. Famakinwa JO. Is the unexamined life worth living or not? Think. 2012; 11(31): 97-103

7. Ehrmann, Bertha, ed. (1948) "The Poems of Max Ehrman" bruce Humphries, Inc. p. 165.

8. The Oath By Hippocrates http://classics.mit.edu/Hippocrates/hippooath.html (accessed 21st May 2018) 